\title{
REQUEST EXPRESSIONS IN THE MOVIE “OBLIVION" BY JOSEPH KOSINKI
}

\author{
Christanto Dwi Nugroho \\ Program Studi Teknik Informatika, \\ Fakultas Teknik dan Ilmu Komputer, Universitas Indraprasta PGRI \\ christantodwinugroho@yahoo.com
}

\begin{abstract}
Abstrak
Tujuan penulisan ini adalah untuk menganalisis ungkapan permohonan. Ada ungkapan langsung permohonan secara sopan, ada ungkapan tidak langsung. Peneliti menggunakan metode deskriptif kualitatif. Terdapat 56 ungkapan langsung permohonan secara sopan, yaitu permohonan langsung 36 (64.2\%), kondisi pernyataan 16 (28.6\%), kondisi pembicara 2 (3.6\%), ungkapan tidak langsung $2(3.6 \%)$. Tergambar bahwa postur kesopanan mendominasi penggunaan kesopanan melalui ucapan aktor dalam menyampaikan ungkapan permohonan 96.6\%. Sementara itu presentasi negatif kesopanan dalam penggunaan strategi kesopanan dalam ungkapan permohonan 5.4\%. Dalam penelitian ini dtemukan seluruh jenis permohonan bisa disampaikan menggunakan strategi kesopanan. Ditemukan ungkapan tidak langsung dapat diungkapkan melalui cara yang sopan. Di dalam ungkapan tidak langsung berdasarkan kondisi dan ungkapan langsung pembicara menggunakan cara yang sopan diungkapkan menggunakan positif dan negatif. Ungkapan tidak langsung 2 (3.6\%) diungkapkan menggunakan cara kesopanan positif, kondisi pembicara juga digunakan positif dan negatif. Enam belas diungkapkan melalui kondisi orientasi setempat $36(64.2 \%), 14(87.5 \%)$ diungkapkan dengan sopan. Sementara $12.5 \%$ menggunakan kesopanan yang negatif. Terakhir adalah permintaan langsung $36(64.2 \%)$ sebagian besar data menggunakan strategi kesopanan positif 35 (97.5\%) yang menggunakan strategi kesopanan negatif (2.8\%).
\end{abstract}

Kata Kunci: Ungkapan permohononan, Film “Oblivion” karya Joseph Kosinki

\begin{abstract}
The purpose of this research is to analyse the expression of the request. There are direct expressions of polite requests, there are indirect expressions. The researcher used a descriptive-qualitative method. There are 56 request expressions for polite expressions, they are: direct request $36(64.2 \%)$, hearer oriented condition $16(28.6 \%)$, speaker-based condition $2(3.6 \%)$, and indirect request $2(3.6 \%)$. Positive politeness dominates the use of politeness strategy by the characters in delivering request expressions with $96.6 \%$. Meanwhile, the percentage of negative politeness in the use of politeness strategy in request expressions is about 5.4\%. In this research found all the types of request expressions can be delivered using politeness strategy. It is found indirect request, speaker based condition and direct request use positive politeness strategy applied using positive and negative politeness. Indirect request 2 (3.6\%) applied using positive politeness strategy. Speaker-based condition also applied using positive and negative politeness. 16 request were expressed by using here-oriented condition 36 (64.2\%). 14 (87.5\%) applied using positive politeness strategy while 2 (12.5\%) using negative politeness. The last is direct request 36 (64.2\%), most of all data use positive politeness strategy 35 (97.2\%). While data used negative politeness strategy (2.8\%).
\end{abstract}

Keywords: Request expression, movie “Oblivion” by Joseph Kosinki 


\section{INTRODUCTION}

A communication is successful if the speaker and the hearer are able to understand each other. It will be successful if the speaker is capable to express or deliver their though, feelings or desires, while the addressee can understand what is meant by the speaker. There are some kinds of utterances which probably threaten the hearer's face, for instance, a request, since when the speaker utter a request, he/she wants the hearer to do something.People need to use certain politeness strategy in order reduce friction in the interaction. Politeness strategy has close realationship with request expression. "Oblivion" is a science-fiction movie produced by Joseph Kosinski. The writer finds that there are some interesting phenomenons containing certain request expressions which apply politeness strategies. To achieve the goal of communication, there must be speaker and addressee. The data of this research will be analyzed in the form of dialogues from the movie "Oblivion". The following example may be useful to clarify the background of study. Victoria (Vika) requests, Can you imagine when we go back up? Having a face to face conversation again? I can't believe it's finally ending." Jack replies, "We made it".

In the example above, Vika makes a request in the form of question. By saying "Can you imagine when we go back up?", she asks Jack's ability to do the request action. She requests him to imagine when they go back up. Moreover, by using this strategy, Vika tries to take Jack's compliance for granted. In this case, Jack complies Vika's request, he says "We made it." Vika also expresses her request using negative politeness in delivering her request. This utterance contain of negative politeness strategy because the speaker redress the hearer's negative face in which the hearer wants to have his/ her freedom of action unhindered and his/ her attention unimpeded. This strategy is used by the speaker to put a social brake on to the course of social interaction by showing a hesitation expression "can you...". Based on the example above, the researcher interested in analyzing the request expressions in the movie "Oblivion" and what types of politeness strategy applied in request expressions in the movie "Oblivion".

\section{Literature Review Pragmatics}

Yule states that :Pragmatics is concerned with the study of utterances meaning communicated by speakers and interpreted by hearers. It focuses on what people mean by their utterances that involve the interpretation of what people mean in a particular context and how the context influences what is said." (Yule, 1996: 4)

\section{Context}

Cutting states that "There are three types of context namely the situational, the background knowledge and the cotextual context." The situational context is what speakers know about what they can see around them. important in order to understand the meaning of utterances (Cutting, 2005: 3).

\section{Speech Acts}

People do not only produce utterance containing grammatical structures and words when they attempt to express themselves, but also perform actions via those utterances. "Actions performed via utterances: are generally called speech acts" (Yule, 1996: 47). Therefore, speech acts are the act performed by a speaker in uttering a sentence. Making an utterance involves a hierarchy of acts, act of utterance. The action performed 
by producing an utterance consists of three related acts. Furthermore, Austin in Levinson divides three kinds of acts, namely locutionary, illocutionary, perlocutionary. Locutionary act is the actual words uttered. It is the act of saying something in the full of sense of 'say' (Levinson, 1983).

\section{Request}

Trosborg "classifies request into four major categories and involves them into eight sub-strategies, they are indirect request, hearer-oriented condition, speaker-based condition, and direct request." (Trosborg, 1995: 192)

\section{Politeness}

According to Yule (Yule, 1996: 60), "Politeness is showing awareness of another person's public self-image". Politeness is closely related to face. Face is based on the practical necessity of showing respect and an intention to preserve the face of other people, their sense of self-esteem, worth, dignity, and unfettered-ness (Brown \& Levinson, 1987). Face means a person's public self-image. It refers to that emotional and social sense of a person, so that every person has and expects everyone else to recognize (Yule, 1996). Face is something that is emotionally invested, and that can be lost, maintained, or enhanced, and must be constantly attended to in an interaction. According to Brown and Levinson, face actually has two aspects, namely negative and positive (Brown \& Levinson, 1987).

\section{RESEARCH METHOD}

Employs the analysis of descriptive and qualitative method. This research belongs to descriptive method as Surakhmad's theory stating that "Descriptive method is a kind of research method using technique of searching, collecting, classifying, analyzing the data, interpreting them, and finally drawing the conclusion" (Surakhmad, 1994: 147). This research also employs qualitative method since the data analyzed are in the form of word or sentence. Furthermore, in a descriptive method, the collected data are in the form of words and/or pictures, not numbers. It is because of the application of qualitative method (Moleong, 2007). By using a descriptive method, it means that people study phenomena and then describe what they have studied. The researcher is the instrument or tool for designing, collecting, and analyzing research. The data in this research include the utterances expressed by words or sentences containing request expression which spoken by the characters in the the movie "Oblivion". The conclusions of descriptive research are only applied to data of the research itself.

\section{RESULT AND DISCUSSION}

\section{The Types of Request Expressions in the Movie "Oblivion"}

\section{Indirect Request}

Indirect request is request without explicit requestive illocutionary force. The speaker omits to mention (or specify) the desired act and avoids mentioning the hearer as the intended agent.

\section{0:23:47 - 00:23:53 (IR/PP)}

Vika : Come on, Jack. You know the regulations. I know you think I'm a stickler but you have no idea what kind of toxins could be in something like that.

Jack : It's a flower, Vika.

\section{Analysis}

Based on the request strategy, Vika's utterance "Come on, Jack. You know the regulations" belongs to indirect 
request. This involves condition of reasonableness. Vika states her reason in making an implicit request. Vika must be able to motivate and justify her desire. She states his desire implicitly. Vika's utterance "Come on, Jack." Is categorized into positive politeness strategy. Vika uses this strategy in order to test Jack and see if he is cooperative. Vika gives several reasons why he asks Jack's help. This is meant to ensure Jack so that he will be willing to help Vika. The effect that can occur after this.

\section{0:23:47 - 00:23:53 (IR/PP)}

Sally : Have your tech stand down?

Vika : copy.

\section{Analysis}

Based on the request strategy, Sally's utterance "Have your tech stand down?" belongs to indirect request. This involves condition of reasonableness. Sally states her reason in making an implicit request. Sally must be able to motivate and justify her desire. She states his desire obviously. Sally's utterance "Have your tech stand down?" Is categorized into positive politeness strategy. Sally uses this strategy in order to test Vika and see if she is cooperative. Sally gives several reasons why she asks Vika's help. This is meant to ensure Vika so that she will be willing to do Sally's order. The effect that can occur after this.

\section{Hearer-oriented condition}

Hearer-oriented condition is request that is "hearer-oriented" convey that the hearer is in a position of control to decide whether or not to perform the request.

\section{0:28:31 - 00:28:34 (HOC/NP)}

Sally : Tower, our logs show you are missing an additional nine fuel cell. Can you confirm?

Vika : Negative, mission, that number is ten.

\section{Analysis}

Based on the request strategy, Sally's utterance " Can you confirm?" belong to hearer-oriented condition. Sally must infer that a question concerning her willingness to carry out the specified act counts as an attempt on the part of Vika to make Vika do so. She uses this strategy because she needs to know Vika's willingness upon her request.

"Can you confirm?" is categorized into negative politeness strategy. Based on Brown and Levinson's theory it is indicated to strategy be conventionally indirect by using the "Can you..." to soften the request. Sally wants to communicate her intention to be indirect even though in fact the utterance goes on record. The utterances "Can you confirm?" cannot be defined as questions of the addressee's potential ability but it should be defined as Sally's desire toward the hearer to fulfill her intention.

\section{0:31:08 - 00:31:24 (HOC/NP)}

Jack : They have some kind of repeater.

The Scavs are using the building as an antenna. Can you decrypt?

Vika : It's a set of coordinates.

\section{Analysis}

Based on the request strategy, Jack's utterance " Can you decrypt?" belong to hearer-oriented condition. Jack must infer that a question concerning his willingness to carry out the specified act counts as an attempt on the part of Vika to make Vika do so. She uses this strategy because she needs to know Vika's willingness upon her request.

$$
\text { "Can you decrypt?" is }
$$

categorized into negative politeness strategy. It might be her trick to ask Vika to do her order. But, by making 'a good story', she tries to save her face in 
order to make Vika accepted her request.

00:36:41 - 00:36:50 (HOC/PP)

Sally : Keep your tech out of there. Do you copy?

Vika : Copy, command. I'm...

00:40:56 - 00:40:57 (HOC/PP)

Vika : Get the med kit!

Jack : (He goes to get the med kit.)

00:42:41 - 00:42:50 (HOC/PP)

Vika : Julia, I'm sorry for what I have to tell you, but you were in crush.

00:43:12 - 00:43:11 (HOC/PP)

Julia : What do you mean?

Vika: You are the only one that made it. I'm sorry.

00:47:11 - 00:47:15 (HOC/PP)

Vika : Let's just get through the night. Okay?

00:50:43 - 00:50:44 (HOC / PP)

Vika: Jack, can you hear me?

Jack: (He does not saying anything.)

00:56:56 - 00:56:57 (HOC/PP)

Vika : Can you confirm the sequence?

Sally : Stand by.

\section{1:23:50 - 01:24:25 (HOC/PP)}

Jack: I was thinking...Why don't you come down with me? To the surface? We could go right now.

The clone of Vika: Now?

Jack: Yeah.

01:42:01 - 01:42:05 (HOC/PP)

Julia: She asks you to bring me up. We'll go together.

01:43:20 - 01:43:21 (HOC/PP)

Julia : Jack..

Jack : Dream of us.

01:51:09 - 01:52:00 (HOC/PP)
Sally: Jack, I can't help notice your respiration and heart rate have increased.

Jack: I'm just excited to finally meet you, Sally.

Sally: There's been a pattern of Insubordinate behaviour recently.

Jack: Yeah. I feel bad about that.

Sally: Voice analysis indicates you are lying to me, Jack.

Tell me why you are here. You have five second.

Jack: I want Julia to live. I want our species to survive. This is the only way.

\section{Speaker-based Condition}

A speaker can choose to focus on speaker-based condition, rather than querying hearer-oriented condition. By placing the speaker's interests above the hearer's, the request becomes more direct in its demand

00:32:03 - 00:32:15 (SBC/PP)

Vika : Tech-49, check your course.

You're headed right for the border. That radiation will cook you from the inside before you know it.

Jack : It's okay, Vika. I see it. I'm gonna do a perimeter check before I head home.

\section{Analysis}

Based on the request strategy, Vika's utterance "Tech-49, check your course" is classified in to Speaker-based conditions. Vika's utterance states her desire to make Jack check his course. Vika's utterance is classified into positive politeness. This involves condition of Hedging opinions. Vika uses this way in order to be vague about her own opinion in order not to beseen as disagreement. The characteristic of hedging opinions is: by using hedges that is used by Vika's utterance "Tech-49, check your course". In expressing her 
desire, Vika conceals her intention due to her position as operator in the team. That is why she uses the hedge to blur it. She tries to give her opinion but she has no power to make sure that she can get what she wants. Jack is the one who holds the control to make the decision. He thinks that as a good team who has a high spirit, it is impossible to leave the mission before finishing it.

Vika also applies positive politeness strategy in delivering her request. Based on Brown and Levinson's Theory, one of some indications of positive politeness is "being optimistic". She says "Tech-49, check your course" because she is confident that Jack will complies the requested action.

\section{0:56:00 - 00:56:10 (SBC/PP)}

Beech : I hope you prove him wrong. Jack : (He does not saying anything.

\section{Analysis}

Based on the request strategy, Beech's utterance "I hope you prove him wrong." is classified in to speaker-based conditions. Beech's utterance states his wishes to make Jack check his course. Beech's utterance is classified into positive politeness. This involves condition of speaker's wishes. Beech uses this way in order to be vague about his own opinion in order not to be seen as disagreement. In expressing his wish, Vika conceals his intention due to his position as the comander of Scavs. Beech's utterance "I hope you prove him wrong." is categorized into positive politeness strategy. Based on Brown and Levinson's theory is indicated that utterance "I hope you prove him wrong" to avoid agreement.

\section{Direct Request}

00:16:21 - 00:16:51 (DIR/PP)

Vika: Requesting back up to his location as soon as possible.

Jack : I've got a visual on drone 172.

\section{Analysis}

Based on the request strategy, Vika's utterance "Requesting back up to his location ASAP." belongs to direct request. The using of as soon as possible structure involves some obligation stemming from a source outside the speaker. Both Vika and Jack are involved in an effective team and they have a mission. Vika's utterance "Requesting back up to his location as soon as possible." Is categorized into positive politeness and applying strategy, use in group identify markers.

\section{0:24:08 - 00:24:10 (DIR/PP)}

Vika : Everyday, you have to go down here and see what was lost.

But we've done our job, Jack. It's time to go.

Jack : I don't think they were trying to kill me today.

\section{0:32:21 - 00:32:24 (DIR/PP)}

Jack : I may go-off, comm.

Vika : Jack, we should keep in contact. Just let me know where you are. Do you copy?Jack, do you copy? Jack : (He does not say anything)

\section{Analysis}

Conversation above show how requestee has to follow requester's command to sit and close his eyes. The request strategy is direct request of imperative that is grammatical form directly signaling that the utterance is an order. In modifying the request, it is modified by lexical/phrasal downgrader of downtoner stated by Typical modifier of "just" to downtone the impositive force of the request. The utterance "Jack, we should keep in contact. "Just let me know where you are. Do you copy? Jack, do you copy?" Is categorized into 
positive politeness and applying the strategy, use in group identify markers.

00:36:31 - 00:36:45 (DIR/PP)

Vika : Jack, mission wanted you to stand down. The drones will handle it.

Jack : That's a negative tower with Tet offline, we need our eyes in this.

00:37:14 - 00:37:30 (DIR/PP)

Vika : I'm ordering you to pull out and return to the tower immediately.

Jack : Touching down.

00:38:07 - 00:38:52 (DIR/PP)

Jack : Tower, we have got survivors. There are four... Check it, five survivors. There are human.

Vika : Jack, the Tet is offline. I have no control.

00:40:35 - 00:40:36 (DIR/PP)

Jack : Open the door! Vika!

Vika: (She opens the door.)

00:41:25 - 00:41:30 (DIR/PP)

Vika : It's breathing fluid. Just let her get it out.

Jack : (He does not saying anything.)

00:42:07 - 00:42:08 (DIR/PP)

Vika : Here, you are still dehydrated.

Julia : (She is drinking the water.)

00:43:49 - 00:43:11 (DIR/PP)

Julia : I've to get back to our ship.

Vika : It's too dangerous down there. You need to take a rest.

00:46:16 - 00:46:20 (DIR/PP)

Vika : If you want to be alone, we understand.

Julia : (She does not say anything.)

00:46:25 - 00:46:30 (DIR/PP)

Vika : I want her gone first thing. Jack : Vika..
00:48:23 - 00:48:39 (DIR / PP)

Julia : I need to get the flight recorder from my ship.

Jack : The Scavs, they move at night. They could be all over it by now.

Julia: I need to know what happened. You need to know what happened. Please...

00:51:09 - 00:51:13 (DIR/PP) Jack : All right, it's time to go. Julia : Jack, I found it.

00:53:00 - 00:53:10 (DIR/PP)

Vika: I know we are low on drones, but, um... requesting one to sweep the area. Just a quick scout.

Sally : Copy 49, tasking 185 to grid 22.

00:54:42 - 00:54:45 (DIR/PP)

Beech: Tell me. Have you ever met a scav up close? Of course not. You just repair the drones.

Jack: (He does not saying anything.)

00:59:47 - 00:59:50 (DIR/PP)

Beech: Let's go! Get him up!

The guards: (They carry Jack to the base)

01:00:49 - 01:01:00 (DIR/PP)

Vika: Permission to task two additional drones?

01:08:17 - 01:09:35 (DIR/PP)

Jack : Vika, open the door.

Vika : Stay away from me. I don't want to hear it.

Jack : It's not safe here. And we need to leave now.

Vika : It was always her. Wasn't it?

Jack : Open the goddamn door!

Vika : No!

01:10:03 - 01:10:05 (DIR/PP)

Jack : Vika, please. We have to go now. 
Vika : I'm not going anywhere with you, Jack.

\section{1:10:21 - 01:10:25 (DIR/PP)}

Vika : Just stay away from me!

Jack : Vika, please there are things.. things you need to know.

Vika : I don't want to know!

01:12:07 - 01:12:10 (DIR/PP)

Sally : It's time to go home, Jack.

Jack : (He does not say anything)

\section{1:16:57 - 01:16:60 (DIR/PP)}

Jack : Wait here.

Julia : (Stay in the plane)

\section{1:18:28 - 01:18:30 (DIR/PP) \\ Jack : Hey! Wait!}

The clone of Jack : Drop your weapon! Jack: It is okay.

The clone of Jack: Don't move!

Jack: We have to shut the drone down.

The clone of Jack : Stop moving!

01:21:33 - 01:21:34 (DIR/PP)

Jack: hold on! Just hold on!

01:36:41 - 01:36:50 (DIR/PP)

Sergeant: Open the door! Spread out! Keep your head down!

01:48:26 - 01:48:30 (DIR/PP)

Jack: I'm going to eject the sleep module. I want you back there now. It's programmed for insertation into earth orbit. I'll fly the Command module out if I break free.

Vika : Absolutely not.

Jack : That's an order.

\section{0:24:34 - 00:25:06 (DIR/PP)}

Jack: The Scavs. They were trying to catch me.

Vika: Well, they can't have you. Come on.

01:56:00 - 01:49:04 (DIR/NP)
Jack's daughter: Mommy, look! Who is that?

Jack: I am Jack Harper. And I'm home. (Subscene.com, 2013)

The frequency and distribution of request expressions are shown in Table 1 below.

Table 1 The frequency of request expressions in

\begin{tabular}{|c|c|c|}
\hline $\begin{array}{l}\text { Types of } \\
\text { request }\end{array}$ & Frequency & Percentage $(\%$ \\
\hline Indirect request & 2 & 3.6 \\
\hline Hearer-oriented & 16 & 28.6 \\
\hline $\begin{array}{l}\text { Speaker-based } \\
\text { condition }\end{array}$ & 2 & 3.6 \\
\hline Direct request & 36 & 64.2 \\
\hline TOTAL & 56 & 100 \\
\hline
\end{tabular}

It can be seen from the table that altogether there were 56 request expressions. 36 requests were expressed by using direct request $36(64.2 \%)$, hearer-oriented condition $16(28.6 \%)$, speaker-based condition 2 (3.6\%), and, $2(3.6 \%)$ indirect request. According to table 1, the characters of "Oblivion" mostly express direct request. From the whole data, there are 36 request expressions that can be classified into direct request. The request explicitly marks utterance as an order.

Direct request that is used by the characters in the movie "Oblivion". Based on the data above contain direct requests in the form of imperative. The imperative is the structure of giving an order directly. It is very authoritative. To soften the imperatives, the speaker may employ tags and/or the marker please. Data in this research also use "please" in the end of utterances to soften the requests. Based on the analysis, the characters emply direct requests when they are in uncontrolled condition. In data the speakers utter direct request because they are too exited 
with something, so they ask directly to get faster reaction from the hearer.

Hearer-oriented condition request that is used by the characters of the movie "Oblivion". Based on the data above, the characters of the movie "Oblivion" employ the strategy of questioning hearer's ability and willingness in delivering their heareroriented condition request. In their hearer-oriented condition request, the hearer is in the position of controlling whether she/he will comply the request action or not. The compliance will depend much on the hearer. There is a possibility for the hearer not comply the order. The physical and mental condition of the hearer and the external situation related to the time, place, etc, of the action will determine the hearer whether she/he may comply the desired action or not.

In this research, there are two request expressions that can be classified into speaker-based condition request. In this category, the request focuses on speaker's interest. Data 18 and 19 show speaker based condition request in the form of wish, so it sounds more polite. In data 18 Vika asks Jack to check his course. She delivers her request by saying "Tech-49, check your course. In data 19, Beech wishes "I hope you prove him wrong".

The last type of requests expressions in the movie "Oblivion" is indirect request. There is only one request expression that can be classified into the indirect request. In this category the speaker omits to mention the desired act and avoids mentioning the hearer as the intend agent. Data 1 and 2 show indirect request namely hinting strategy. In data 1 Vika asks, "Come on, Jack. You know the regulations." Vika does not explicitly mention her desire about Jack's invitation. In data 2 Sally asks, "Have your tech stand down". Sally does not explicitly mention her desire to order the Tech to out of the site.

\section{The use of Politeness Strategies in the Movie "Oblivion"}

In this research, there are many data contain possitive politeness. The positive politeness that used by the characters in the movie "Oblivion" can be found in the most of data. The detail information about the use possitive politeness strategy can be seen in the table 2 below.

Table 2 The frequency and distribution of the use of politeness strategies in the movie

\begin{tabular}{|l|c|c|}
\multicolumn{1}{|c|}{ "Oblivion" } \\
\multicolumn{1}{|c|}{$\begin{array}{c}\text { Types of } \\
\text { Politeness }\end{array}$} & Frequency & $\begin{array}{c}\text { Percentage } \\
(\%)\end{array}$ \\
\hline $\begin{array}{l}\text { Positive } \\
\text { Politeness } \\
\text { Negative } \\
\text { Politeness }\end{array}$ & 53 & 94.6 \\
\hline \multicolumn{1}{|c|}{ TOTAL } & $\mathbf{5 6}$ & 5.4 \\
\hline
\end{tabular}

It can be seen from table 2 that positive politeness dominates the use of politeness strategy by the characters in delivering request expressions with $94.6 \%$. the characters mostly mix their requests with positive politeness because they already know each other. The speakers deliver request to someone who has close/intimate relationship with them, so they do not need to use formal language in expressing their requests. They also use negative politeness to show friendliness. It is important because if the speaker treats the hearer properly as friend, it will increase the possibility from the hearer to comply the requested action. Meanwhile, the percentage of negative politeness in the use of politeness strategy in request expressions is about $5.4 \%$.

\section{CONCLUSION}

In understanding the speaker's request, the listener must have mutual background knowledge. Speaker has two 
strategies in delivering the request; they are direct and indirect request. If the speaker wants his/her request needs to be granted immediately, he/she should apply the direct request. Meanwhile, speaker can apply the indirect strategy in order to soften his/her request. Besides, this strategy is used to can save the speaker's face in case his/her request is rejected. From the research conducted in this study, the request can be revealed by Trosborg's theory (1995) and Brown and Levinson (1987). There are 56 request expressions. 36 requests were expressed by using direct request $36(64.2 \%)$, hearer-oriented condition 16 (28.6\%), speaker-based condition 2 (3.6\%), and indirect request 2 (3.6\%). Positive politeness dominates the use of politeness strategy by the characters in delivering request expressions with $94.6 \%$. Meanwhile, the percentage of negative politeness in the use of politeness strategy in request expressions is about $5.4 \%$. In this research found all the types of request expressions can be delivered using politeness strategy. It found indirect request, speaker based condition, and direct request use possitive politness strategy applied using positive and negative politeness. Indirect request $2(3.6 \%)$ applied using positive politeness strategy. Speaker-based condition also applied using positive politeness. 16 requests were expressed by using hearer-oriented condition, 14 $(87.5 \%)$ applied using positive politeness strategy while $2(12.5 \%)$ applied using negative politeness. The last is direct request $36(64.2 \%)$, most of all data use positive politeness strategy, $35(97.2 \%)$, while 1 data uses negative politeness strategy $(2.8 \%)$.

\section{REFERENCES}

Brown, P., \& Levinson, S. C. (1987). Politeness: Some universals in language usage (Vol. 4). Cambridge University Press.

Cutting, J. (2005). Pragmatics and discourse: A resource book for students. Routledge.

Levinson, S. C. (1983). Pragmatics. In Cambridge UK. Cambridge: Cambridge University Press.

Moleong, L. J. (2007). Metodologi penelitian kualitatif. Bandung: PT Remaja Rosdakarya Offset.

Subscene.com. (2013). Subtitlesoblivion. Retrieved April 6, 2014, from Subscene.com website: Subscene.com/subtitles/oblivion2013/English/760754

Surakhmad, W. (1994). Pengantar penelitian ilmiah: dasar, metode, dan teknik. Bandung: Tarsito.

Trosborg, A. (1995). Interlanguage pragmatics: requests, complaints and apologies. New York, NY: Mouton de Gruyter.

Yule, G. (1996). Pragmatics: Oxford University Press. Oxford. 